\title{
France lays plans for a green future
}

A recipe: take a roomful of French farmers, fishermen, trade unionists, captains of industry and environmentalists, then mix in scientists and politicians. Ask them to come up with an agreed blueprint for a green revolution in France and leave them to simmer for ten weeks. It might seem a rich dish, but last week these unlikely bedfellows surprised many, including themselves, by reaching a consensus on proposals for almost everything from climate change to biodiversity. Their recommendations (see 'Key proposals') will be finalized at a summit chaired by France's president, Nicolas Sarkozy, at the end of October.

Environmental progress in France

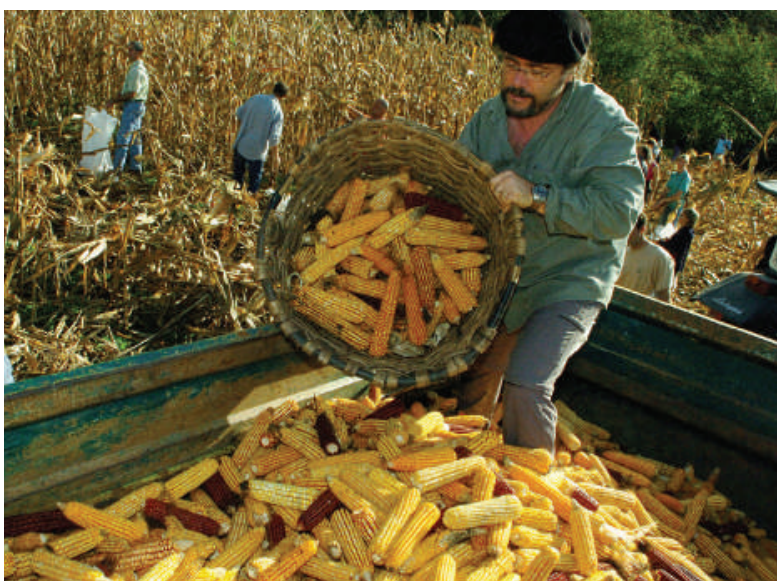

Organic farming in France could make up 20\% of production by 2020.

unusual for scientists to be confronted so directly with the rest of the population," he explains. By the end, though, he says he was impressed by the other groups' appetite for understanding how research could help the process. Having scientists on tap, and not on top, turned out to be no bad thing either, says Le Maho. Politicians and others did a better job brokering the issues than scientists ever could, he adds.

As the weeks went by, groups found common ground, says Guillou. "There was a chemistry that worked." Everyone realized they were facing a real problem, adds Jouzel, echoing the words of JeanLouis Borloo, minister of ecology and sustainable development: "We have no lags badly behind that of some of its European neighbours, such as Germany and Scandinavia. But Sarkozy made the greening of France a major plank of his election campaign this year. He has since created a superministry for ecology, biodiversity and sustainable development, with responsibility for the powerful sectors of transport, energy and construction - a first in France, where ecology was previously off the political radar (see Nature 447, 518; 2007).

Scientists involved in this vast whirlwind arbitration say the exercise marks a first in the handling of science-based issues in France. Gathering the main sectors of society - including environmental groups, long shunned in France - round the same table is a new experiment in democracy, says Marion Guillou, president and chief executive of Paris-based INRA, Europe's largest agricultural research agency. The consultation is called the Environmental Grenelle, in reference to the Paris area where the 1968 government held talks with unions and industry to end weeks of rioting and strikes. It has given the greens a strong voice for the first

time, environmentalists say. "It's the first time in France that we have all the main groups and the government talking ecology and the environment," says Daniel Richard, president of conservation group WWF France, and spokesman for Alliance for the Planet, a consortium of 80 French ecological organizations.

\section{Honest brokers}

"It was an historic experiment, and was a success," agrees Jean Jouzel, a climatologist who heads the Institut Pierre-Simon Laplace in Paris, and who is France's representative on the Intergovernmental Panel on Climate Change. Consensus was far from obvious in July at the start of the exercise, says Jouzel, who cochaired the Grenelle working group on climate change with Nicholas Stern, economic adviser to the UK government and author of an influential 2006 report on climate change.

Yvon Le Maho, a biodiversity researcher at the Hubert Curien Multidisciplinary Institute in Strasbourg, felt some discomfort in such broad socio-economic negotiations. "It's

\section{Key proposals}

- All newly built homes to produce more energy than they consume by 2020. Renovate all existing buildings to save energy. Ban incandescent light bulbs by 2010. Reduce greenhouse-gas emission by $20 \%$ by 2020 . - Increase renewable energy from $9 \%$ to $20-25 \%$ of total energy consumption by 2020 . - Bring transport emissions back to 1990 levels. Reduce vehicle speed limits by 10 kilometres per hour. Taxes and incentives to favour clean cars. Shift half of haulage by road to rail and water within 15 years. Develop rail and public transport. - Reduce air pollutants quantitatively. - Create a national network of 'green' corridors and nature reserves.

- Increase organic farming from $2 \%$ to $6 \%$ of total acreage production by 2010 and to $20 \%$ by 2020 . - Ecological groups to be stakeholders, like trade unions, in government negotiations. - Create a body to review planting of genetically modified crops on a case-by-case basis. alternative but to radically change the rules and bring about an environmental revolution."

But despite the wide consensus on many areas, two major issues, the future of nuclear power - which meets nearly $80 \%$ of France's electricity needs - and the planting of genetically modified crops, eluded agreement. The meetings were too short to overcome existing entrenched positions here, Guillou says regretfully. Sarkozy has made it clear that there will be no scaling back of nuclear power. The government's final position on genetically modified crops is less clear. Although these seem set to face tighter restrictions with the proposed creation of a separate body to consider approvals on a case-by-case basis, a moratorium cannot be ruled out.

The groups' conclusions, released on $27 \mathrm{Sep}$ tember, include 60 pages of recommendations, and more than 1,000 pages of conclusions from some 300 participants in 8 working groups. They are now open to public consultation on the Internet, with the government deciding on its final actions at the October summit.

But Richard knows this is only the start. In the next phase the rosy consensus among stakeholders will give way to lobbying on what gets implemented and how, he predicts. But the proposals agreed on have strengthened the hand of the sustainable-development agenda, he says. Farmers have agreed to cut pesticide use, Richard points out. "That's new; now it is a question of negotiating by how much, and by when."

Guillou agrees that the Environmental Grenelle marks a watershed in France. "Something happened," she says, "there has been a convergence." But she adds that it will require research agencies like her own to adapt.

Declan Butler 